\title{
Isolated Megacisterna Magna in a Fetus with Trisomy 21: Case Report
}

\author{
21. Kromozom Trizomisi Olan Bir Fetüste \\ İzole Megasisterna Magna
}

\author{
Alper KAHRAMAN, ${ }^{a}$ \\ FIrat TÜLEK, ${ }^{a}$ \\ Ayşegül ALKILIÇ, \\ Salih TAŞKIN, ${ }^{a}$ \\ Acar KOÇa
}

aDepartment of Gynecology and Obstetrics, Ankara University Faculty of Medicine Ankara

Geliş Tarihi/Received: 26.10 .2013

Kabul Tarihi/Accepted: 28.02.2014

Yazışma Adresi/Correspondence:

FIrat TÜLEK

Ankara University Faculty of Medicine, Department of Gynecology and Obstetrics, Ankara,

TÜRKIYE/TURKEY

firattulek@yahoo.com

\begin{abstract}
Megacisterna magna is classicaly defined as a cisterna magna measured above 10 milimeter. There is limited data in literature about outcomes of isolated cisterna magna enlargement. These limited amount of data indicates normal neonatal and developmental outcomes however shortness of the available evidences about the outcomes of isolated cisterna magna enlargement render this issue confounding. Here we present a case with an isolated enlarged cisterna magna that was shown to have trisomy 21 afterwards. This is the second case with isolated cisterna magna enlargement reported to have trisomy 21 in the literature. A mild association between cisterna magna enlargement and chromosomal anomalies could be existing particularly with trisomy 21 . Risk of chromosomal anomalies should be kept in mind when counselling the patients with isolated cisterna magna enlargement.
\end{abstract}

Key Words: Down syndrome; cisterna magna; aneuploidy; cranial fossa, posterior

ÖZET Megasisterna magna terimi klasik olarak 10 milimetreden daha büyük ölçülen sisterna magna için kullanılır. İzole sisterna magna genişlemesinin sonuçları ile ilgili literatürde sınırlı veri bulunmaktadır. Bu sınırlı veriler normal neonatal ve gelişimsel sonuçlara işaret etmekle birlikte verilerin kısıtlı olması bu konuyu şüpheli kılmaktadır. Burada daha sonra trizomi 21 olduğu gösterilen fetal izole sisterna magna genişlemesi saptanmış bir olgu sunmaktayız. Bu trizomi 21 olduğu gösterilen literatürdeki ikinci izole sisterna magna olgusudur. Sınırlılıkları dikkate alındığında, literatürdeki veriler aksine işaret etse de özellikle trizomi 21 ile olmak üzere sisterna magna genişlemesi ve kromozomal anomaliler arasında zayıf bir ilişki bulunuyor olabilir. İzole sisterna magna genişlemesi bulunan olgulara öneriler yapılırken kromozomal anomali riski de göz önünde bulundurulmalıdır.

Anahtar Kelimeler: Down sendromu; sisterna magna; anöploidi; kafa çukuru,arka

Turkiye Klinikleri J Gynecol Obst 2015;25(1):47-9

doi: 10.5336/gynobstet.2013-37951

Copyright $\odot 2015$ by Türkiye Klinikleri isterna magna is located in the posterior fossa of the brain dorsal to the cerebellum and it contains cerebrospinal fluid. It links to the fourth ventricle by foramen Magendie and foramen Luschka. Cisterna magna could be accepted as enlarged if the anteroposterior diameter between dorsal aspect of the cerebellar vermis and inner edge of the occipital bone was measured larger than $10 \mathrm{~mm} .{ }^{1}$ There is limited data in literature about outcomes of isolated cisterna magna enlargement. These limited amount of data indicates normal neonatal and developmental outcomes however shortness of the available evidences about the outcomes of iso- 
lated cisterna magna enlargement render this issue confounding. Here we present a case with an isolated enlarged cisterna magna that was shown to have trisomy 21 afterwards.

\section{CASE REPORT}

A 26 years old woman in her second pregnancy was referred at 34 weeks of gestation. Both the patient and her partner are free from any medical comorbidities. Family history was unremarkable. Her pregnancy follow-up was normal until an enlarged cisterna magna was measured as 16,1 milimeter at 34 weeks of gestation. Her first and second trimester screening tests were within normal limits. Nuchal translucency was measured as 1,9 milimeter at ultrasound performed at 11 weeks of gestation. Detailed ultrasound examination performed at 24 weeks of gestation was completely normal including the cisterna magna measurement. An enlarged cisterna magna measuring 16.1 milimeter was revealed at ultrasound examination performed on 34 weeks of gestation (Figure 1). Cerebellar structures, ventricles and other intracranial structures were all normal. Ultrasound examination did not reveal any other abnormalities including polyhydramnios, oligohyramnios, cardiac or limb abnormalities. Fetal biometric measurements were all compatible with the gestational age. Patient's anxiety was alleviated in consideration to the current evidences about isolated cisterna magna enlargement. Subsequent pregnancy follow-up was normal. Cesaraen section was performed at 38 weeks 6 days of gestation due to previous cesarean section. A 3450 gram female neonate was born. Apgar scores were $9 / 10$. Initial physical examinations revealed phenotypic appereances of trisomy 21 such as increased inter-ocular distance up-slanting palpebral fissures, medial epicanthal folds, flat nasal bridge and simian creases. Neonatal abdominal ultrasound examination and transfontanelle ultrasound examination were normal. Ophtalmologic examination was not revealed any ocular findings or stigmas of Down syndrome. Postnatal ecocardiography revealed a patent foramen ovale. Neonatal karyotyping revelead a 47, XX+21 chromosomal structure.

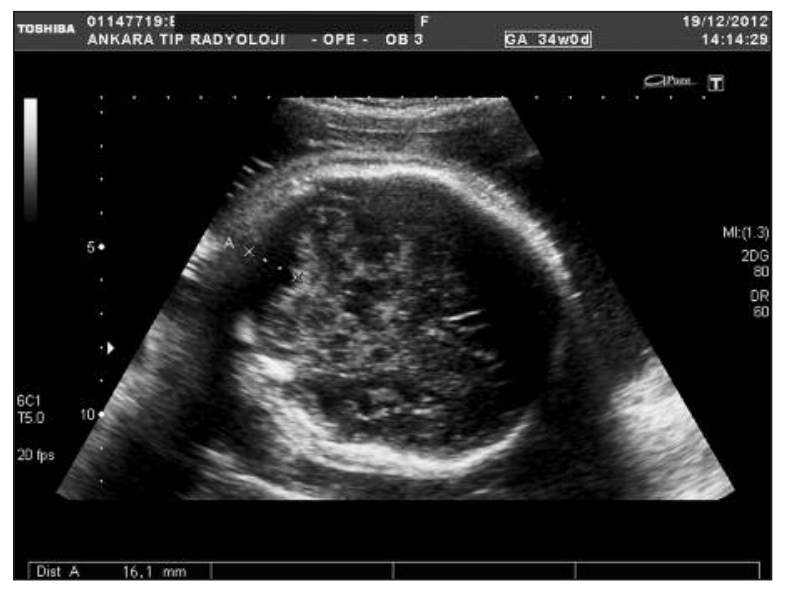

FIGURE 1: Axial section of fetal head at 34 weeks of gestation demonstrating an enlarged cisterna magna measured as $16,1 \mathrm{~mm}$. Cerebellar vermis is apparent in this section.

\section{DISCUSSION}

Cisterna magna lies between cerebellum and occipital bone in posterior fossa and connected to the fourth ventricle by foramen Magendie and foramen Luschka. Cisterna magna enlargement was defined as more than $10 \mathrm{~mm}$ lenght between dorsal aspect of the cerebellar vermis and inner edge of the occipital bone. ${ }^{1}$ Measurements should be done at a plane in the level of cavum septum pellucidum, cerebral peduncles and cerebellar hemispheres. ${ }^{2}$ Posterior fossa development is thought to be completed between 18-22 weeks of gestation and some authors do not recommend to make a diagnosis of any forms of vermian hypoplasia before $24^{\text {th }}$ gestational week. ${ }^{3}$ Upper limit of normal cisterna magna measurement varies due to gestational age. A study conducted by Twickler et al. revealed upper limit of normal cisterna magna approaches to $15 \mathrm{~mm}$ in 40 weeks of gestation with $95 \%$ confidence interval. ${ }^{4}$ This study demonstrated that accepting 10 $\mathrm{mm}$ as the cut off value of normal cisterna magna measurement may lead to false positive diagnosis in third trimester. Even in these circumstances the presented case seems like to has an enlarged cisterna magna with its measurement of $16,1 \mathrm{~mm}$.

An enlarged cisterna magna could also be seen as a component of Dandy-Walker malformation. This malformation also includes cystic dilatation of fourth ventricle and hypoplasia or agenesis of cere- 
bellar vermis. An enlarged cisterna magna in association with Dandy-Walker malformation could be associated with alcohol, warfarin, rubella, toxoplasmosis, isoretinoin exposures, diabetes and also chromosomal abnormalities like trisomy 13 and trisomy $18 .^{1,5}$

Outcomes of isolated cisterna magna enlargement has not been clearly demonstrated yet. Current evidences about this issue indicates usually normal fetal and neonatal outcomes. Forzano et al. published a series of fetuses with isolated cisterna magna enlargement and all of the fetuses found to have normal outcomes at up to 5 months neonatal follow-ups. ${ }^{6}$ In a study conducted by Haimovici et al. 15 fetuses with isolated cisterna magna enlargement presented. All of the pregnancies resulted with phenotypically normal liveborn neonates. ${ }^{7}$ Dror et al. compared 29 children with a diagnosis of enlarged cisterna magna established in utero and 35 normal children. Children with enlarged cisterna magna showed a significiant delay in walking ages moreover these children showed significiantly lower scores in visual and social subtests of Gessel developmental schedule even if the scores were still within the normal ranges. ${ }^{8}$ Except the presented one, there is only one case reported in the literature with an isolated cisterna magna that was demonstrated to has trisomy 21 . That case was reported to have low risk second trimester screening test, a dilated umblical vein $(7 \mathrm{~mm})$ and enlarged cisterna magna $(12 \mathrm{~mm})$ without cerebellar hypoplasia detected at 24 weeks of gestation. ${ }^{9}$ As distinct from the case reported by Lai et al. in this case cisterna magna enlargement was detected in third trimester, after the posterior fossa has completed its development. Authors of this report proposed that enlarged cisterna magna without cerebellar hypoplasia could be a previously overlooked rare structural anomaly related to trisomy 21 , probably with a small incidence. ${ }^{9}$ The presented case is supporting this proposal despite these two case reports are surely insufficient to make suggestions in counselling about outcomes of fetuses with isolated enlarged cisterna magna. However when considered the shortness of available evidences about the issue, these cases could be kept in mind that indicate a mild association could also exist between isolated cisterna magna and chromosomal abnormalities. Further studies with larger sample sizes needed to clarify this issue.

\section{REFERENCES}

1. Pilu G. Ultrasound evaluation of the fetal neural axis. In: Callen $\mathrm{P}$, ed. Ultrasonography in Obstetrics and Gynecology. $5^{\text {th }}$ ed. Philadelphia, PA: WB Saunders Co; 2008. p.363-91.

2. McGahan JP. The fetal head: borderlines. Semin Ultrasound CT MR 1998;19(4):31828.

3. Malinger G, Lev D, Lerman-Sagie T. The fetal cerebellum. Pitfalls in diagnosis and management. Prenat Diagn 2009;29(4):372-80.

4. Twickler DM, Reichel T, Mclntire DD, Magee KP, Ramus RM. Fetal central nervous system ventricle and cisterna magna measurements by magnetic resonance imaging. Am J Obstet Gynecol 2002;187(4):927-31.

5. Nyberg DA, Mahony BS, Hegge FN, Hickok D, Luthy DA, Kapur R. Enlarged cisterna magna and the Dandy-Walker malformation: factors associated with chromosome abnormalities. Obstet Gynecol 1991;77(3):436-42.

6. Forzano F, Mansour S, lerullo A, Homfray T, Thilaganathan B. Posterior fossa malformation in fetuses: a report of 56 further cases and a review of the literature. Prenat Diagn 2007;27(6):495-501.

7. Haimovici JA, Doubilet PM, Benson CB,
Frates MC. Clinical significance of isolated enlargement of the cisterna magna ( $\& \mathrm{gt} ; 10 \mathrm{~mm}$ ) on prenatal sonography. J Ultrasound Med 1997;16(11):731-4; quiz 735-6.

8. Dror R, Malinger G, Ben-Sira L, Lev D, Pick CG, Lerman-Sagie T. Developmental outcome of children with enlargement of the cisterna magna identified in utero. J Child Neurol 2009;24(12):1486-92.

9. Lai TH, Cheng YM, Chang FM. Prenatal diagnosis of trisomy 21 in a fetus with an enlarged cisterna magna. Ultrasound Obstet Gynecol 2002;20(4):413-5. 